\title{
IMPROVING THE STUDENTS' READING COMPREHENSION THROUGH THE USE OF SUGGESTOPEDIA METHOD
}

\author{
${ }^{1}$ Adi Chandra, ${ }^{2}$ Yuneva and ${ }^{3}$ Elva Utami \\ ${ }^{1,2,3}$ English Education Department of Prof. Dr. Hazairin, S.H University, Indonesia \\ e-mail: ${ }^{1}$ adichandra305@yahoo.com, ${ }^{2}$ yuneva12@gmail.com,${ }^{3}$ utamielva80@gmail.com.
}

Received on February, $18^{\text {th }}$, Revised on March, $24^{\text {th }}$, Published on July, $30^{\text {th }} 2020$

\begin{abstract}
The objective of the research was to get empirical evidenceof the improving students' reading comprehension of narrative text through suggestopedia method. The method of this research was classroom action research which was conducted in two cycles. The subject of this research was the Second Grade Students of SMA Pesantren Pancasila Bengkulu at Academic Year 2017/2018 with total number of students 18 . The research instruments were the observation sheet, interview guidelines, questionnaire and test form. Based on the results of data analysis of pre-test and post-test shown the significant improvement. The average score of pre-test was 54,05 . It means two students' score could pass the KKM. It was $11,11 \%$ passed the learning outcome. The average score of post-test 1 was 72,94 . It proved that $44,44 \%$ students passed KKM. The average score of post-test 2 was 82,77 . Then, it was obtained that the percentage of students who could get the score above the KKM in post-test 2 was $100 \%$. Based on the learning activities which have occurred the enhancing from the first to second cycle. From this research findings, it showed that suggestopedia method could improve the students' reading comprehension of narrative text.
\end{abstract}

Keywords : Improving, Narrative Text, Suggestopedia Method and Classroom Action Research.

\begin{abstract}
ABSTRAK
Tujuan penelitian ini adalah untuk mendapatkan bukti empiris peningkatan pemahaman bacaan siswa terhadap teks naratif melalui metode sugestopedia. Metode penelitian ini adalah penelitian tindakan kelas yang dilaksanakan dalam dua siklus. Subjek penelitian ini adalah siswa kelas X SMA Pesantren Pancasila Bengkulu Tahun Ajaran 2017/2018 yang berjumlah 18 siswa. Instrumen penelitian berupa lembar observasi, pedoman wawancara, angket dan tes. Berdasarkan hasil analisis data pre-test dan post-test menunjukkan peningkatan yang signifikan. Nilai rata-rata pre-test adalah 54,05. Artinya, nilai dua siswa bisa lulus KKM. Sebanyak 11,11\% dinyatakan lulus hasil belajar. Skor rata-rata post-test 1 adalah 72,94. Terbukti 44,44\% siswa dinyatakan lulus KKM. Nilai rata-rata post-test 2 adalah 82,77. Kemudian diperoleh persentase siswa yang memperoleh nilai di atas KKM pada post-test 2 adalah $100 \%$. Berdasarkan kegiatan pembelajaran yang diberikan terjadi peningkatan dari siklus I ke siklus II. Dari hasil penelitian menunjukkan bahwa metode sugestopedia dapat meningkatkan pemahaman bacaan siswa terhadap teks naratif.
\end{abstract}

Kata Kunci: Teks Naratif, Metode Suggestopedia, dan Penelitian Tindakan Kelas. 


\section{INTRODUCTION}

English as an international language which is use to communicate with other people in the world. English is very important for education in Indonesia because the government of Indonesia has decided that English is one of the compulsory subjects for senior high school which have four major language skills that should be mastered by students during their period of learning in school. Students are expected to be success in learning English through mastering both language skills and language components. English is a unity that cannot be separated.

Language skills are listening, reading, speaking, and writing. Language components contain vocabulary, structure, and pronunciation. The students should be able to apply those skills and components in their habitual activities and social environment. In order to be successful in using English as means communication, the students have to be capable of all of the language skill. So we need to equip students to be able to master English well. According to Harmer (2007 : 99) Reading is useful for language acquisition.

Reading is one of the important academic language skills in English in addition to the ability to speak, hear and write. By reading, we can get more informations, knowledge, enjoyments and problems solving from what we see like symbols and texts. According to Yousef (2006 : 64), reading is a process between the reader and the text that leads to automaticity. Actually, reading is the easiest and the cheapest way to get information, because it can help to know the simple information to the more complex one. In addition, the main important thing that the readers should have the ability to comprehend they have read. According to Royer (2004 : 1), reading comprehension is the process of understanding and constructing meaning from a piece of text. Moreover, reading comprehension may be affected by the difficulty of the text, the vocabulary used in the text, and the readers familiarity with the subject matter, among other factors.

Based on the observation, the students of SMA Pesantren Pancasila has lacked in reading comprehension. They has a bad thought of reading comprehension. They also feel that reading is a difficult skill and text was a bored activity. During reading activities, students can not focus on what they read because the classroom environment does not support them to read well. Moreover, because they find it difficult to understand the text, many students feel bored to participate in class activities. In 
(Bambang Yudi Cahyono, 2010: 48) states, “ for many people, reading can sometimes be very complicated since it very often requires certain skills so that reading can become activity for restoring input from written text". It means that reading makes the students difficult to understand written text. Then, the teachers just explain the problem in front of the class without any interaction between teacher and students and then assignment to individual students.

The teacher must choose the suitable strategy to make the process of teaching reading comprehension running well. The education takes the role of teachers as educators and teachers are professionals, material relevant to the needs, appropriate methods to achieve the objectives, the evaluation as a tool to measure the capabilities and infrastructures to support learning activities. The way teachers in the learning process especially in reading should be designed to motivate students ability in understanding the texts. Teachers must also be good at choosing appropriate methods to present the material. Therefore, the teachers should be able to format the teaching method as interesting as possible. It needs an appropriate method to overcome those problems.

In this research, the researcher intends to overcome the problems to improve students' reading comprehension by using suggestopedia method. Suggestopedia, one of the strangest "humanistic approaches" was developed in the 1970's by the Bulgarian educator Georgi Lozanov. Lozanov believes that in the learning process the students use an unconscious mind by giving positive suggestion to make the students relax and concentrate. The suggestopedia methods in teaching English is that suggestopedia methods have different class setting which make the students relax during the learning process. Using music rhythm is used in the teaching learning process (Harmer, 2001, p.90). Music in the learning process background helps to make students focus and concentrate to the material. Venkanna \& Glorry, (2015 : 130) added that the effect of physical surrounding and pleasant atmosphere of the classroom can make the students relaxed, confident and comfortable in reading the text because they do not feel under pressure to learn in the classroom. The purpose of this method is to make the students relax and enjoy during the learning process. So, in order to get relaxed mind, beside by using music, suggestopedia methods also decorate the class with posters or something which can make students mind relax, such as by putting flowers or aquarium in the corner of the class. We can put some posters which contain of 
motivation words or posters which contain of our lesson. So when the students look at the posters, they have learn some new vocabularies. Beside that, suggestopedia class a range chairs in the class into semicircle shape. It is aimed to make students more focuses on the lesson.

Based on the statement of the problem above, the objective of this research was to find out improvement the students' in reading comprehension through suggestopedia method at the second grade students of SMA Pesantren Pancasila Bengkulu.

\section{METHODOLOGY}

This research employed an action research method. The researcher used classroom action research as the method of the research. According to Pine (2009 : 30) Classroom action research is a process of concurrently inquiring about problems and taking action to solve them. It is sustained, intentional, recursive, and dynamic process of inquiry in which the teacher taken an action-purposefully and ethically in specific classroom context to improve teaching/learning.

The research on improving students' reading comprehension through suggestopedia method at Sma Pesantren Pancasila Bengkulu is an action research study. It attempted to find the solution of the problems and implement actual actions in improving a condition by showing the causeeffect relationship between the actions and the results. The researcher use the model developed Kemmis and McTaggart (1988) in Burns (2010 : 8) propose a model of a classical action research. There were some other models of action research, but they were criticized by Kemmis and McTaggart as being too fixed and inflexible. In doing this action research, the researcher considered phases which were involved in each cycle. They were planning, action, observation, and reflection. Every phase was done based on the researcher's ideas on the research.

The population of this research was the second grade students of SMA Pesantren Pancasila divided into class IPA and IPS . Class IPA consists of 18 students while class IPS consists of 16 students. Therefore, the populations of this research are 34 students. Then, the sampling term use in the study refers to the process of selecting individuals who will participate (eg, observed or questioned) in a study (Fraenkel and Wallen 2005: 111). The underlying reason for the researcher conducting classroom action research in Second Grade IPA is because reading comprehension is considered to be lacking. They tend to be less interested in 
English subjects, there is less motivation to learn reading comprehension especially reading text.

Furthermore There were three instruments that the researcher used in conducting a research, they were observation, test, and interview. The research do the observation directly toward English teaching and learning-process in second grade of Sma Pesantren Pancasila. Stake (2010: 90) states that observation can allow the researcher to get the information which can be seen, heard, or felt directly. In this research, The research acted as an active observer. The observations carried out to observe the behavior of students, student responses, and assessment of students' learning methods used when they are reading. When the learning process takes place, the researcher considered the suitability of the learning stages that has been agreed. The learning stages that carried should be directed to the goal of improving reading skills.

The test was used to compare students' reading comprehension achievements before conducting the research and after conducting the research. The form of the test is the written test. Pre-test and post test are kind of the test that will measure the students' scores in reinforcing their reading comprehension. Both of pre-test and post-test are presented in translating the text and essay form. The test is used to measure the level of students' reading comprehension. There were pre-test and post-test. Pre-test was conducted before the researcher did the action. Meanwhile, post-test was held if last cycle was done.

One of the ways to get deep and more information in the classroom is by using interview. Stake (2010: 95) argues that interview enables the researcher to obtain the unique information or interpretation from many people and to find out things that the researcher cannot observe by herself. In this research, interview was done by the researcher so that she could know how the English teacher and students' responses, opinion, suggestion, and expectation while and after doing the implementation of Suggestopedia method in the teaching and learning process of reading, clarify their idea about the technique being implemented, and reflect the students' practices. The interview was about problem in reading comprehension lesson before and after using suggestopedia method activities in reading lesson.

\section{FINDING AND DISCUSSION}

The research was conducted to find out the improving of the students' reading comprehension in narrative text through the use of suggestopedia method. Suggestopedia Method was one of many learning strategy 
which this method the use of music in the learning process to make students relax and enjoy during the learning process. This research had proved that Suggestopedia method was effective to be used in teaching reading comprehension especially in narrative text. It can be seen in the table 1 of the students'.

Table 1. The Students' Scores of Pre-test

\begin{tabular}{|c|c|c|c|c|}
\hline \multirow[t]{2}{*}{ No } & \multirow{2}{*}{$\begin{array}{l}\text { The Name of } \\
\text { Students }\end{array}$} & \multicolumn{2}{|c|}{ Score } & \multirow{2}{*}{$\begin{array}{c}\text { Categor } \\
\mathbf{y}\end{array}$} \\
\hline & & $\begin{array}{c}\mathbf{K} \\
\mathbf{K} \\
\mathbf{M}\end{array}$ & $\begin{array}{l}\text { Pre- } \\
\text { test }\end{array}$ & \\
\hline 1 & AKMAL WAHID & 75 & - & Failed \\
\hline 2 & ALES & 75 & 57 & Failed \\
\hline 3 & ANZHENI & 75 & - & Failed \\
\hline 4 & $\begin{array}{l}\text { FAJRI AL - } \\
\text { AZHAR }\end{array}$ & 75 & 57 & Failed \\
\hline 5 & $\begin{array}{l}\text { FALENTRI SICI } \\
\text { FATWA }\end{array}$ & 75 & 53 & Failed \\
\hline 6 & FIA MERSIANA & 75 & 60 & Failed \\
\hline 7 & $\begin{array}{l}\text { HOLIYEN } \\
\text { ROYES }\end{array}$ & 75 & 63 & Failed \\
\hline 8 & INDRIANI & 75 & 53 & Failed \\
\hline 9 & $\begin{array}{l}\text { KARTINI DWI } \\
\text { HASANAH }\end{array}$ & 75 & 57 & Failed \\
\hline 10 & LENSI HERLINA & 75 & 47 & Failed \\
\hline 11 & M. ALFAROZY & 75 & 63 & Failed \\
\hline 12 & $\begin{array}{l}\text { MONIKA DWI } \\
\text { ANGGITA }\end{array}$ & 75 & 63 & Failed \\
\hline 13 & $\begin{array}{l}\text { NANDA ARDHI } \\
\text { IBRAHIM }\end{array}$ & 75 & 63 & Failed \\
\hline
\end{tabular}

\begin{tabular}{|clccc}
\hline $\mathbf{1 4}$ & ROHMAT HOIRI & 75 & 70 & Failed \\
$\mathbf{1 5}$ & $\begin{array}{l}\text { SUGI HARTO } \\
\text { SAPUTRA }\end{array}$ & 75 & 77 & Passed \\
$\mathbf{1 6}$ & $\begin{array}{l}\text { TIARA } \\
\text { YULIARSIH }\end{array}$ & 75 & 77 & Passed \\
$\mathbf{1 7}$ & $\begin{array}{l}\text { YELLYTA } \\
\text { PAHLEVI ESA } \\
\text { PUTRI }\end{array}$ & 75 & 53 & Failed \\
18 & PUTRI AULIA & 75 & 60 & Failed \\
\hline & \multicolumn{1}{|c|}{ Total } & $\sum \mathrm{x}=973$ & Failed \\
& & $\mathrm{X}=54,05$ & \\
\hline
\end{tabular}

Based on the above table, the pre-test results show that 2 students' passed. The Pre-test obtained the average students' score is 54,05 . This proves the students still lack of Based on the above table, the pre-test results show that 2 students' passed. The Pre-test obtained the average students' score is 54,05 . This proves the students still lack of understanding the ability to reading comprehension in narrative text.

While, The post test 1 and 2 that was conducted after the researcher taught the students in two meetings every cycle. The post-test 1 was conducted on May 6th 2018 as after the researcher taught the students in two meeting in cycle. The result of post test 1 can be seen seen in the following table. 
Table 2 The Students' Scores of Post-test in Cycle 1

\begin{tabular}{|c|c|c|c|}
\hline No & $\begin{array}{l}\text { The Name of } \\
\text { Students }\end{array}$ & Score & Catagory \\
\hline & & 4 & Good \\
\hline 1 & AKMAL WAHID & 3 & Good Enough \\
\hline 2 & ALES & 3 & Good Enough \\
\hline 3 & ANZHENI & 4 & Good \\
\hline 4 & $\begin{array}{l}\text { FAJRI AL - } \\
\text { AZHAR }\end{array}$ & 4 & Good \\
\hline 5 & $\begin{array}{l}\text { FALENTRI SICI } \\
\text { FATWA }\end{array}$ & 4 & Good \\
\hline 6 & FIA MERSIANA & 4 & Good \\
\hline 7 & $\begin{array}{l}\text { HOLIYEN } \\
\text { ROYES }\end{array}$ & 4 & Good \\
\hline 8 & INDRIANI & 3 & Good enough \\
\hline 9 & $\begin{array}{l}\text { KARTINI DWI } \\
\text { HASANAH }\end{array}$ & 4 & Good \\
\hline 10 & $\begin{array}{l}\text { LENSI } \\
\text { HERLINA }\end{array}$ & 4 & Good \\
\hline
\end{tabular}

Based on the above table, the result of post-test in cycle 1 shows an increase in students' scores. There are 8 of the students' passed. The Post-test 1 obtained the average students' score is 72,94 . The post test 1 was conducted after the researcher taught the students in two meetings at the last session of the cycle.

The post-test 2 was conducted on May 19th 2018 as the last session of the cycle 2 . The result of post test can be seen seen in the following table.

\section{Table 3 The Students' Score of Post-test in Cycle 2}

\begin{tabular}{|c|c|c|c|c|}
\hline \multirow[t]{2}{*}{ No } & \multirow{2}{*}{$\begin{array}{l}\text { The Name of } \\
\text { Students }\end{array}$} & \multicolumn{2}{|c|}{ Score } & \multirow{2}{*}{$\begin{array}{c}\text { Categ } \\
\text { ory }\end{array}$} \\
\hline & & KKM & $\begin{array}{l}\text { Post- } \\
\text { test } 2\end{array}$ & \\
\hline $\mathbf{1}$ & $\begin{array}{l}\text { AKMAL } \\
\text { WAHID }\end{array}$ & 75 & 80 & Passed \\
\hline 2 & ALES & 75 & 77 & Passed \\
\hline 3 & ANZHENI & 75 & 77 & Passed \\
\hline 4 & $\begin{array}{l}\text { FAJRI AL - } \\
\text { AZHAR }\end{array}$ & 75 & 80 & Passed \\
\hline 5 & $\begin{array}{l}\text { FALENTRI SICI } \\
\text { FATWA }\end{array}$ & 75 & 87 & Passed \\
\hline 6 & FIA MERSIANA & 75 & 83 & Passed \\
\hline 7 & $\begin{array}{l}\text { HOLIYEN } \\
\text { ROYES }\end{array}$ & 75 & 83 & Passed \\
\hline 8 & INDRIANI & 75 & 87 & Passed \\
\hline 9 & $\begin{array}{l}\text { KARTINI DWI } \\
\text { HASANAH }\end{array}$ & 75 & 83 & Passed \\
\hline 10 & $\begin{array}{l}\text { LENSI } \\
\text { HERLINA }\end{array}$ & 75 & 80 & Passed \\
\hline 11 & M. ALFAROZY & 75 & 83 & Passed \\
\hline 12 & $\begin{array}{l}\text { MONIKA DWI } \\
\text { ANGGITA }\end{array}$ & 75 & 77 & Passed \\
\hline 13 & $\begin{array}{l}\text { NANDA ARDHI } \\
\text { IBRAHIM }\end{array}$ & 75 & 83 & Passed \\
\hline 14 & $\begin{array}{l}\text { ROHMAT } \\
\text { HOIRI }\end{array}$ & 75 & 90 & Passed \\
\hline 15 & $\begin{array}{l}\text { SUGI HARTO } \\
\text { SAPUTRA }\end{array}$ & 75 & 90 & Passed \\
\hline 16 & TIARA & 75 & 87 & Passed \\
\hline
\end{tabular}




\begin{tabular}{|c|c|c|c|c|}
\hline & YULIARSIH & & & \\
\hline 17 & $\begin{array}{l}\text { YELLYTA } \\
\text { PAHLEVI ESA } \\
\text { PUTRI }\end{array}$ & 75 & 80 & Passed \\
\hline 18 & PUTRI AULIA & 75 & 83 & Passed \\
\hline & Total & \multicolumn{2}{|c|}{$\sum \mathrm{x}=1490$} & Passed \\
\hline & & \multicolumn{2}{|c|}{$X=82,77$} & \\
\hline
\end{tabular}

Based on the above table, The cycle 2 was a significant change from cycle 1 . The Post-test 2 results show that all of the students' passed with the average students' score is 82,77 . The Post-test 2 was an increase in implemented learning with suggestopedia method.

\section{CONCLUSION}

After implementing Classroom Action Research at the second grade Students of SMA PANCASILA Bengkulu and according to the result of any tests, it could be summarized that there was a significant difference before and after implementing suggestopedia method in teaching narrative text. It was that used suggestopedia in teaching reading is helpful, especially in improving students' reading comprehension of narrative text. It can be shown from the result of pre-test and some post-test.
Furthermore, the students' improvement of reading comprehension of narrative text can be seen clearly in the students' improvement score of their achievement in pre-test and two post-tests. The result of pre-test and post-test shown the significant improvement. The average score of pre-test was 54,05 . It means none only $11,11 \%$ of the whole students was passed the learning outcome (KKM). The average score of post-test 1 was 72,94 . It proved that $44,44 \%$ students passed learning outcome (KKM). The average score of post-test 2 was 82,77. Then, it was obtained that the percentage of students who could get the score above the learning outcome (KKM) in post-test 2 was $100 \%$. It can be concluded that teaching narrative text by using suggestopedia method, could improved students' reading comprehension of narrative text.

\section{REFERENCES}

Alyousef, H. S. 2006. Teaching reading comprehension to ESL/EFL Learners. Journal of Language and Learning, 5(1), 379-380

Harmer, J. 2009. How to Teach English. New Edition. Essex: Pearson Education Limited, p. 10.

Pine, G.J. (2009). Teacher action research: building knowledge democracies. London: Sage, p. 19. 
Royer, R. 2004. Reading the Web. Information technology and teacher education annual. Norfolk, VA: Association for the Advancement for Computing in Education.

Venkanna, K., \& Glorry, N. 2015. “ Use of suggestopedia as an innovative strategy for promoting effective reading comprehension abilities in English at the ESL level" An experimental study. International Journal of English Language, Literature and Humanities, 3(8), 128149. 